\title{
David Clapham: Remaking housing policy: an international study
}

\section{Routledge, 2018, 226 pp, ISBN: 978-1-138-19393-2}

\section{Marja Elsinga ${ }^{1}$}

Published online: 23 May 2020

(c) Springer Nature B.V. 2020

This book reflects on more than 30 years of neoliberalism in housing policy. It is written by a close witness who explains why neoliberalism had a huge impact on housing; probably far more than the 1990s housing experts he was among might have expected. David Clapham succeeds in describing the impact of neoliberalism on housing around five key concepts: privatisation, marketisation, commodification, financialisation and individualisation.

This journal serves the housing research community I am part of. However, I need to declare that as part of a faculty of architecture, I learned that "housing (policy)" has quite a negative and neoliberal connotation among architects as well as urban planners. Urbanists emphasise housing as part of the neighbourhood and environment, whereas architects prefer the word "dwelling" over "housing", since it is about the way people live. So, housing is more than a physical structure produced by markets and supported or not by housing policies. In his 12 chapters, Clapham makes it very clear that he masters this complexity of the topic.

This book is very multidimensional and ambitious in analysing policies and therefore a great follow-up to "The meaning of Housing: a pathway approach (2005)" that focuses on households. I very much appreciate his selection of topics in these chapters. He thoroughly digs out the mechanisms and consequences of the neoliberal powers and manages to go beyond mere markets and policies. For example, he devotes chapters to neighbourhoods, homelessness and environmental sustainability. The chapters are nicely illustrated with six different cases. The selection of cases/countries, however, is rather unbalanced: UK is very dominant in the book; there are two other Anglo-Saxon cases (USA and Australia); and then three others from different continents (China, Argentina and Sweden). It made me pause, to think if this a matter of access to material, or does it illustrate an Anglo-centrist world view?

The first chapter explains the aim of the book: analysing the neoliberal discourse and building an argument to guide readers to think beyond this discourse. The second chapter deals with housing policy and explains how the neoliberal thinking influenced policy, resulting in a shift of policy instruments. It concludes by emphasising the importance of

Marja Elsinga

m.g.elsinga@tudelft.nl

1 Faculty of Architecture and the Built Environment, Delft University of Technology, Delft, The Netherlands 
shared values and political ideology and, more in particular, equality and sustainability. The third chapter deals with housing regimes and explains a number of approaches: welfare regimes, path dependency and varieties of capitalism. It also presents housing regimes represented by the six "cases" that will play a role in the rest of the book.

Chapter 4 deals with housing markets and housing finance and concludes that housing is a special commodity, such that governments should develop policies, since they consider market outcomes as unacceptable. The next chapter (Ch 5) deals with housing and home, and "affordability" of home and its implications for the definition of a "good house". Therefore, the "judgements" of householders are key in formulating evaluations of what is good housing, according to Clapham. This is itself a fascinating conclusion, which is a bit underexposed in the concluding chapter 12 .

Chapter 6 deals with neighbourhoods and brings in the town/urban planning dimension. The chapter concludes that "interventions at the neighbourhood level reinforces the need to tackle housing problems at source rather than where the symptoms arise". The next chapter deals with housing supply and concludes that financialisation has resulted in a focus on the short term. Moreover, China is presented as a prominent example of government provision of social housing. Some more explanation of context would have been fruitful here.

Chapter 8 deals with distribution and affordability of housing and describes different policy instruments applied in the different cases. It is interesting how Clapham puts these topics in the perspective of social justice and the rentier economy. Chapter 9 is about state-provided housing, and again, to my surprise, the example of China is used as "proof" for the state as being the most effective way to increase housing supply, necessary to support the economy. However, he missed a second key driver in China, and that is the role of public housing for social stability. Homelessness, the ultimate failure of housing provision, is the topic of the next chapter (Ch 10). It compares the rights-based approach in UK with others and results in a very insightful chapter. Environmental sustainability is dealt with in the next chapter (Ch 11). This is a rather modest chapter on a topic that can easily fill complete books, but the link to the core of the book is insightful: defining housing problems in terms of sustainability can be a way to move forward.

Chapter 12 is the main piece of this book, offering food for thought about housing policy beyond neoliberalism. Clapham describes, very well, what future policies should not be and comes up with some preliminary ideas for what future policies might embrace, such as through taxation instruments and state provision. He continues with four principles for an alternative housing regime: housing as human right, well-being, equality and sustainability, and identifies the excluded younger generation and new social movements of those affected by housing shortage as carriers of the new regime. He seems to be very positive about state provision and uses China as an example, but provides no clue as to how this could engender political support in other countries. I am not convinced here, and, frankly, I am a bit disappointed about the last chapter in which I hoped to find more ingredients for new housing policy regimes. This might, however, rather more reflect my high expectations of David Clapham, than the quality of the final chapter of this fascinating book. He ends the book with the need for a "critical juncture" to change the paradigm in housing in 2019, not knowing about the Covid-19 crisis as being a possible critical juncture to remake housing into a human-rights-based one.

The book is an excellent textbook for both graduates and undergraduates in housing, planning, social policy, geography and architecture. It helps students to quickly grasp what housing policy is about and very well explains all the different dimensions of housing. Some better quality photographs would make the book even more attractive. 
The book is also a "must-read" for academics and policymakers active in the field of housing. It very well explains how neoliberal thinking became dominant in all corners of the housing field and provides fertile ground to feed the debate on what is next.

Publisher's Note Springer Nature remains neutral with regard to jurisdictional claims in published maps and institutional affiliations. 